\title{
State-Centric Realism Eclipsed: TNCs as the Rising Powerful Actors in the Age of Trade Liberalization
}

\author{
Wei-en $\operatorname{Tan}^{1}$ \\ ${ }^{1}$ Graduate Institute of International Politics, National Chung Hsing University, Taichung City, Taiwan \\ Correspondence: Wei-en Tan, 250 Kuo Kuang Rd., Taichung 402, Taiwan. Tel: 1-886-936-099912. E-mail: \\ jakobs@nchu.edu.tw
}

Received: August 21, 2015

Accepted: August 31, 2015 Online Published: November 29, 2015

doi:10.5539/jpl.v8n4p223

URL: http://dx.doi.org/10.5539/jpl.v8n4p223

\begin{abstract}
This essay argues that the global trade liberalization, particularly since 1995, strengthens some transnational corporations (TNCs) to become more powerful. In this sense, some statements argued by state-centric realism have to be revised; however, doing that does not mean that realism is fully out-of-date. The case studies suggest that mother country, such as the U.S., is a critical agent for TNCs to project their power and/or to protect their vital interest in the global market. In other word, sovereign state, especially the stronger one, is still important under some specific conditions. Ironically, most countries in the global south are increasingly retreating from the stage of international trade while TNCs from the North are detaining many efficient means of control over technology, capital and even political access.
\end{abstract}

Keywords: TNCs, sovereign state, trade liberalization, state-centric realism

\section{Introduction}

Everywhere, nowadays, is evidence that transnational trade and technological changes are transforming the world in every dimension. Trade, instead of sovereign state, and people are therefore more closely linked than ever before. Advances in communication and transportation technologies coincided with the accelerated globalization lead countries to become more interdependent through a rapid increase in cross-border movement of goods and capital (Kose \& Ozturk, 2014: 7). Transnational corporations (TNCs), undoubtedly, have become a new rising actor on the stage of global politics during this period in which they exercise their influence on lots of issues (Cutler, 2002).

This paper provides a power-centric explanation but not necessarily associated with a sovereign state as what conventional wisdoms, particularly the realism's viewpoints, usually claim for. The argument here is that sovereign states are scarcely de facto independent, particularly those who are closely related to global trade. Actors (both states and non-state ones) on the stage of international trade that have comparative advantage in doing business are the real power-owner; put otherwise, country is very likely an agent for TNCs. This paper also suggests that traditionally state-centric realists should seriously pay their attention on the impact caused by the global trade liberalization since the phenomenon: quiet politics - frequently exists in the process of reducing the influence of sovereign states and their governments by making international trade free from domestic regulations. ${ }^{1}$

The rest of this paper is structured as follows. In Section 2, the key terms are defined and introduced. In Section 3 , it presents the analytical framework that is particularly based on two opposite perspectives regarding the interaction between TNCs and sovereign states, and then explains the components of "power". A detailed account based on the observed case studies will be given in the Section 4. The last Section summaries research findings from the three cases and contends that the hypothesis based on state-centric realism does not fully reflect the reality in the field of international trade.

\section{The Definitions of Critical Concepts}

\subsection{Sovereign State}

The Montevideo Convention on Statehood of 1933 sets out four necessary requirements for Statehood. They are:

\footnotetext{
${ }^{1}$ The phenomenon of quiet politics is usually invisible until the so-called focusing events happened. See: Culpepper, 2010.
} 
(1) a permanent population, (2) a defined territory, (3) government and (4) the capacity to entire into relations with other States. The Convention and prevailing idea in the field of international law identify sovereign states as a kind of sui generis legal entity operating and existing under its own authority. Article 3 of the same Convention provides, "The political existence of the state is independent of recognition by the other states. Even before recognition the state has the right to defend its integrity and independence, to provide for its conservation and prosperity, and consequently to organize itself as it sees fit, to legislate upon its interests, administer its services, and to define the jurisdiction and competence of its courts."2

However, in the age of global trade liberalization, states are more vulnerable to markets where once markets were regulated and controlled by states (Strange, 1996). As such, the understanding of sovereign state in the field of international political economy (IPE) should be adjusted and certainly different from the definition argued by international lawyers. According to Susan Strange, "the nature of the competition between states in the international system has fundamentally changed." (Strange, 1995: 55). The reason is because of that sovereign state as a political organization to defend people against violence beyond its territory still exists, but this function in many countries (most of them are developing countries) is obviously at a much lower level. Today, choosing the appropriate form of capitalist development is generally thought to be the foremost mission that the states should take (Frankel, 2000: 45-50). In this transformation period, one interesting question is worth paying attention; namely whether or not sovereign states still have independent freedom to choose the development strategy as what they did in the period without global trade liberalization (Frankel, 2006: 25-27).

Indeed, in the contemporary world, we have to accept that there is a transformation in economic dynamics. Technological advances are bringing about profound changes in our daily life. Specifically, the key features of globalization are the growth of foreign direct investment (FDI) and global trade from the 1980's to date emphasizes the role of TNCs in the global politics (UNCTAD, 1992). As global trade liberalization increases the significance of the TNCs, this paper suggests that more and more TNCs increasingly tend to gain the upper hand in competition within the sovereign states and their governments under some conditions. ${ }^{3}$

\subsection{TNCS}

The definitions of TNCs vary but for the purposes of this paper the term 'transnational corporation' means a profit-seeking industry associated with two critical characteristics (Scherer, et. al., 2006: 512-515). First, it engages in the diversity of business activities - including production, manufacturing, processing, distribution as well as research and development - outside the country of origin so that such actors run their business in two or more countries. Second, every single TNC must have a "parent company," located in the country of origin (the mother country) that exercises an administrative influence over its subsidiaries around the world. The second characteristic is essential which reminds us that the interaction between a mother country and its TNCs would at least have two possibilities: (1) Partner Type, which means that mother countries support their TNCs and vice versa; (2) Adversary Type, which shows that home governments limit outward foreign investment or are not eager to help develop their TNCs for many reasons. ${ }^{4}$

Generally, the influence of TNCs over sovereign states very often, particularly and usually in the relatively less-developed countries, has not only been manifest in economic dimension but has also been reflected in their ability to exert political leverage directly or indirectly through participating on local economic policy within in the host countries. Furthermore, TNCs prefer to enlist the help of their mother countries to further or protect their market interests. For instance, American businessmen in 1930s bought large plots of land in Central America and shipped bananas to the United States, and a very prominent American TNC called the United Fruit Company (UFC) almost controlled the entirely local trade of banana. At this period, the term "Banana Empire" or "Banana Republic" emerged since the UFC held incredible economic power and even political influence on countries in Central America. In the 1950s, the UFC clearly showed how much power it has when the Guatemalan government attempted to take back its land. What was surprised, the US government, backed by the UFC and some other banana companies, overthrew the government by Guatemalans, and deliberately supported a new president who favored banana industry's interests (Wiley, 2008: 37-55).

\footnotetext{
${ }^{2}$ Please see: https://www.ilsa.org/jessup/jessup15/Montevideo\%20Convention.pdf (last visited: 2015/08/21)

${ }^{3}$ I do not argue that sovereign states themselves are obsolete. By contrast, they are still influential and critical in the international relations. Yet they are increasingly becoming weak; in other word, the inner core of their authority or capability of control over economic and trade activities within their defined territorial borders is seriously impaired.

${ }^{4}$ For instance, the former ROC President Lee Teng-hui initiated the "Go Slow, Be Patient" policy in order to safeguard Taiwan's national security preventing from Taiwan's excessive trade dependence on mainland China. See: Fell, 2012: 162.
} 


\subsection{Quite Politics}

Some professional issues, e.g., the food safety standard of using Ractopamine, often do not rank high on the political agenda before the focusing event reported (Birkland, 1998: 53-74), but actually have political consequences to some degree. Unlike other salience issues which usually be addressed by variations in government partisanship or interest group coalitions, one phenomenon called 'quiet politics' argued here is a focal point to understand what exactly happened in low-salience but very political and controversial.

For instance, Wei-Chuan Foods Corp, Taiwan's second-largest food manufacturer, was found to have sold food products made with gutter oil, a potentially harmful mixture of waste oil recycled from restaurant fryers and slaughterhouse byproducts. In fact, before this extremely focusing event discovered, the chairman of Wei-Chuan Food Corp-Wei Ying-Chun had a very good connection with many officials and politicians by donating over NT\$200 million in cash under the table. What it more, Mr. Wei was also a member of a fan club for President Ma, which is composed of business group representatives during the 2012 presidential election campaign (Taipei Times, 2014).

Given the absence of governments and people's attention of food safety or the high technicality of some professional issues, it undoubtedly is obvious that neither governments nor citizens are sensitive and able to know the truth about trade affairs. Briefly speaking, the market under the corporate control constitutes a threat for sovereignty (Turner, 1997: 306; Naím, 2013). According to Moisés Naím (2013) and Jeffry Frieden (2006), TNCs so often succeed in creating a regulatory environment that largely serves their interests. Actually, before noisy politics arise around the issues that generate significant and sustained interest by large numbers of voters, many countries and their governments will not think that governing low-salience issues is in their interest. Quiet politics, therefore, arises in the context of issues with low salience, such as food ingredients derived from GMOs or labor rights abuses committed by contracts reducing the influence and supervision of sovereign states.

\section{Analytical Framework \& Components of Power}

This section introduces a power-centric theory but does not limit its concern on sovereign state as the only power owner. In a globalized world with high level trade liberalization, immeasurable commodities are frequently exchanged across the territorial boundaries of sovereign states but regulated by more global trade rules rather than conventionally domestic jurisdiction (Patterson \& Afilalo, 2008: 135).

Global trade governance grows so solidly and irreversibly because of advancements in goods production technology and the proliferation of trade liberalization as a universal value. Given this, the vast sovereign states are difficult to exercise absolute authority over their domestic markets, and at the international level global trade regimes such as the World Trade Organization (WTO) focus predominantly on issues about the access to markets (e.g., goods transported from exporting countries to importing countries). ${ }^{5}$ In short, the concept of market access comes hand in hand with trade liberalization as the two sides of the same coin, and is strengthened by the legal obligation of "National Treatment" and "Most Favored Nation" under the WTO system (Joyce, 2013: 6-7). As a consequence, sovereign states probably are still the dominant actors de jure, but they are already not the most powerful actors de facto as state-centric realist argues in the field of trade issues.

In this sense, the following part gives an assessable definition of "power" as a strategy in testing two mutually exclusive hypotheses below: ${ }^{6}$

\section{$\dagger$ H1: If TNCs begin to take the upper hand in international trade,}

Sovereign states lose control of their autonomy and also lose control over the domestic market. This outcome will particularly be observed in those issues with low salience happened in some countries.

\section{†H2: If sovereign states still seize upper hand in international trade,}

TNCs tend to easily get into trouble with the recipient countries (including target countries and host countries) more often because of accusation of stealing natural resources and exploiting local economy (Vernon, 1976).

The two competing hypotheses above will be tested by three case studies later. For the sake of hypotheses testing, however, the foremost step is to provide a concept of "power," and then to explain how this paper assesses it.

\footnotetext{
${ }^{5}$ For instance, the WTO imposed on China very stringent requirements when it became a member of it in December 2001 after 15 years of negotiations. These requirements concerned the reduction of tariffs, the opening of many service sectors to foreign competition and the protection of intellectual property rights.

${ }^{6}$ Before going to the case study, it is necessary to mention about two competing hypotheses. The first one, as Susan Strange argued, is intended to challenge the realist understanding of sovereign states. By contrast, the second hypothesis stands with realism in the perspective of conventional wisdom.
} 


\subsection{The Definition of Power}

Michael Barnett and Raymond Duvall claim that the "account for how global activities are guided and how world orders are produced...requires careful and explicit analysis of the workings of power." (Barnett \& Duvall, 2005: 2). However, if not over exaggerated, almost everyone in the field of international relations (IR) knows that just how complicated and contested the concept of power is. Namely to do a solid analysis of or to provide a compelling research on any issues regarding power is by no means easy.

Traditionally, much of the students in IR tend to treat power as the ability of one actor $\mathbf{X}$ to use something to get another actor $\mathbf{Y}$ to do what it otherwise would not do (Dahl, 1957: 202-203), at least somehow and someway. Bear in mind, in the real world power actually works in various forms that cannot be understood precisely by such a brief description. The following, therefore, reexamines the current interpretation of power, offering a new conceptualized definition which captures a specific form that power takes in the issue area of international trade, and also demonstrates why this revised definition is theoretically valid, and also favors our understanding of quiet politics.

\subsubsection{Conceptualization}

The central concern includes a consideration of under what conditions - which issue, when and how-some actors have power over others. The first and foremost step corresponding with this concern is to narrow down power in a background with two dimensions: direct and indirect. When we talk about direct power, by and large there is an agreement among IR scholars that power should be analyzed in terms of capability (Baldwin, 2013: 274-275). The reason is not only because the term 'capability' in general usage represents that one actor has direct control over another, but also because both power and capability are fundamentally the same in their nature according to Waltz's understanding (1979: 60-61). When we think about indirect power, in contrast to direct one, actors adjust their strategy by exercising disguised restriction on others through institutions or rules in a way that work to their advantage and to the disadvantage of others (Drezner, 2007). As a matter of fact, this approach to exercise power is more time-consuming and usually needs sophisticated diplomatic policies based on abundant human resources and professional knowledge. Thus, compared with direct power, both developing countries and their TNCs usually are more difficult to use indirect power than their northern counterparts.

Apart from two categories of power, the second step is to emphasize that power is not only frequently but also fairly important for coordinating some common goals between or among actors (Stein, 1993: 41). According to this view, it is not hard to imagine that international trade take place very often within an unequal distribution of power at the international level, and to witness some actors are better positioned than others in the bargaining process in which the most powerful actors can actually affect outcomes at one specific issue area by influencing the setting of "principles, norms, rules, and decision-making procedures."7

The two steps above have to be integrated with some extra explanations. First of all, there must be a conflict of interest at some degree. In other words, actor $\mathbf{X}$ and $\mathbf{Y}$ want different outcomes respectively; however, actor $\mathbf{Y}$ is subordinate in its interaction with actor $\mathbf{X}$. Secondly, actor $\mathbf{X}$ has the upper hand because it has more "material and/or ideational resources that lead actor $\mathbf{Y}$ to have no choice but to alter its actions." (Barnett \& Duvall, 2005: 13). The added explanations are indispensable because many IR scholars, doing their studies of power, pay too much attention on how one actor is able to use material resources to advance its own interests in straightforward opposition to the interests of other actors. However, in the real world, particularly in global trade, actors who are powerful prefer to exert their power by not using force directly; conversely, they exert their power by setting the rules of game and designing solid institutions (Duffield, 2003: 416-417). ${ }^{8}$

\subsubsection{The Formation of A Revised Definition}

According to the discussion above, it is able to develop a new definition that promises to be inclusive of what are commonly regarded as the most important attributes power has without losing analytical validity. In this sense, the concept of power is systematically revised as follows:

A performance, in a given case where one specific conflict of interest between (or among) actors, shows that actor $\boldsymbol{X}$ uses direct power to get another actor $\boldsymbol{Y}$ to do what it otherwise would not do, and/or uses institutional power indirectly to cause actor $\boldsymbol{Y}$ to give up its interests to some extent at least.

On the basis of this definition of power, here tries to provide some indicators for judging cases in the issue of

\footnotetext{
${ }^{7}$ See: Drezner, 2007; Krasner, 1982: 186. Nevertheless, both direct and indirect power are influenced by the distribution of power among different actors. In other words, the structure of power matters in any cases (Cooper, et. al., 2008).

${ }^{8}$ A similar understanding, "forum-shopping," can be seen in: Drezner, 2007: 29-38.
} 
global trade. First of all, under the WTO system, even though all member states have one vote legally, some specific ones, such as the U.S. and the European Union (EU), ${ }^{9}$ significantly wield more power in global trade sector because of their strong governments as well as their TNCs with advanced technology. In other words, state capability and technology level together play a critical role in the process of global trade realizationion (Grieco \& Ikenberry, 2002).

Next, this paper looks at how the actors shape and deploy trade regime globally to advance their own interests over other actors' by exerting indirect power. In consideration of some specific actors that are able to combine their power in the market with professional information and knowledge in the setting of rules, or through harnessing their home governments as agents for their interests by using such information and knowledge (Hertz, 2003), people can discover that many trade agendas are driven by specific actors rather than others (Tan \& Tsai, 2012).

Besides direct power (including state capability and technology level) and indirect power (consisted of professional knowledge in setting rules), there are the other two attributes within the definition of power: (1) one specific conflict of interest and (2) the outcome in which actor $\mathbf{Y}$ (the weaker one) gives up its interests. In respect of the conflict of interest, the indicator is whether or not one actor (or actors) filed a complaint against another actor (or actors) within the WTO. The accurate information can be refereed from the WTO official website. ${ }^{10}$ With respect to one actor's (or actors') renouncement, this paper suggests that actor $\mathbf{Y}$ through an act declares or shows that identified interests in the conflict with actor $\mathbf{X}$ (the stronger one) are given up eventually. For the sake of observation, the dispute settlement final result is a useful indicator.

\section{The Case Studies}

TNCs are one of the most important non-state actors in the field of global trade, frequently using their commercial and even political leverage to influence international negotiations and take advantage of a worldwide trend towards economic liberalism (Levy \& Prakash, 2003: 137-139; Harrison, 1997: 5). Moreover, TNCs are powerful enough to exert considerable influence on the economic and trade policies of many sovereign states. For instance, although the WTO is made up of sovereign states or separated customs territories, it is TNCs rather than these WTO members that run businesses in the real world. Given this, people will not be surprised that WTO's practice is usually in line with TNCs expectation and member states' trade policy is dominated by a set of TNCs interests (Dahan, et. al., 2006: 1582).

As mentioned earlier, the banana companies belonging to developed countries were very powerful and influential in political and economic activities in developing countries. This section will introduce the in-depth case studies, showing how TNCs operated their capability beyond borders and brought themselves advantages in relation to other actors in the stage of global trade. ${ }^{11}$ The first case demonstrates that Chiquita Company played a central role in the involvement of the U.S. government in the trade dispute (Josling, 2003). The second case indicates that Kodak Company actively supported the U.S. government to file a trade suit against Japan (Fletcher, 1996). Since the U.S. government and its TNCs, as powerful international actors argued by the conventional wisdom, are involved in the first two cases, the third one looks at the trade dispute between developing countries and their TNCs, preventing from the problem of selection bias.

\section{Case 1: The Banana Trade War}

The lion's share of global trade in bananas has been undertaken, directly or indirectly, by a small number of TNCs. Among them, the top three are Chiquita, Dole and Del Monte. Chiquita as the fruit giant with a huge world's banana market share is significantly powerful through incorporating a chain from production, shipping to distribution. This integration strategy is facilitated by technological inputs for cultivation, warehousing and storage (Shah, 2010).

After the establishment of the WTO, Chiquita argued that the European Communities' restriction on banana imports was the cause of the company's financial distress. Further, it believed that the EC's failure to comply with the WTO agreements violated the principles such as non-discrimination. Based on these violations, the EC

\footnotetext{
9 According to the WTO, until November $30^{\text {th }} 2009$, the title of the EU officially was the "European Communities (EC)". Since then (the Treaty of Lisbon enforced), the EU succeeded the EC and its 28 members nowadays also enjoy their full memberships in the WTO. See: http://www.wto.org/english/thewto_e/countries_e/european_communities_e.htm (last visited: 2015/11/20)

10 Additionally, the lists of WTO/DSM panel and Appellate Body reports are available at: http://www.worldtradelaw.net/reports/wtopanels/wtopanels.asp $\quad$ (last $\quad$ visited: $\quad 2015 / 08 / 21) \quad$ and http://www.worldtradelaw.net/reports/wtoab/abreports.asp (last visited: 2015/11/20)

${ }^{11}$ Such actors in particular are: mother countries, host (or target) countries, and the WTO (a sort of trade institutions).
} 
was responsible for the company's 50\% decrease in market share of bananas in Europe since 1993. In the same period, the U.S. government was responding to a massive lobbying effort by Chiquita (FAO, 2003). It is worth mentioning that "within 24 hours" of the White House's announcement that it may bring a lawsuit to challenge the EC's trade policy, Chiquita made a US\$500,000 donation to Democratic parties (The Guardian, 1999).

The case above raises a critical question about the true goal of the U.S. government, particularly in light of the fact that the interests allegedly injured by the EC banana policy are located outside the States. The WTO Panel report, issued in 1997, found that the EC banana import regime was discriminatory and inconsistent with the obligation under the WTO agreements. The Appellate Body report issued in the same year later, granting the EC 15 months to comply with what it should do (WTO, 1997). Chiquita was the winner undoubtedly.

\section{Case 2: The Photographic Film and Paper Trade War}

In consumer photographic film, Kodak and Fuji separately dominated their home markets and had comparable market shares in the rest of the world in the early 1990s. However, Kodak casted doubts on that the Japanese government deliberately tolerated some private anticompetitive practices which caused the limitation of market access and fair competition. Moreover, Kodak alleges that Fuji controls the distribution system for consumer photographic film. As such, Kodak was unable to access to the Japanese market because Fuji controls the distribution system through its dominance of the primary wholesalers around the entire Japan (Baron, 1997).

Kodak decided to give pressure on the U.S. government to care this trade dispute in high priority through political lobbying and the enlistment of allies, particularly in Congress. Given this, the U.S. Trade Representative realized that it will be the subject of congressional inquiry if it did not address this problem. In the long run, this case was turned over to the WTO. On December $5^{\text {th }}, 1997$ the WTO Panel ruled against Kodak and the U.S. government, deciding that "the Japanese Government's actions, some of which took place 30 years ago, did not amount to restrictions on international trade." (WTO, 1998). Simultaneously, Fuji released a comment, saying, "We hope that Kodak stops relying on its political power and returns to fair competition in the Japanese market." (Lida, 2006: 114).

Compared to the first case study, Kodak Company did not gain the upper hand in the power struggle with the Japanese government but it still demonstrated that the U.S. national trade policy was largely determined by the preferences of Kodak's managers, and such result does remind us that Japan as one advanced country is capable of claiming something that might be the opposite of what the U.S. wants to accomplish (in contrast to the EC mentioned above).

\section{Case 3: The Chicken War}

In Brazil, the poultry industry employs more than 3.6 million people direct or indirectly, and accounts for roughly $1.5 \%$ of GDP. In the exports, Brazil keeps its position as the largest poultry exporter to more than one hundred countries. The brilliant performance of Brazilian poultry industry can be attributed to the abundance of land, fertile soil, advanced technology, and the investments in research and development by some big companies in the last few years (Unesi, 2008). There are two leading companies, Sadia and Perdigao, which together account for nearly half of Brazil's export of poultry. Sadia has lots of divisions situated in different regions around the world, maintaining a close connection to its buyers or potential consumers. Perdigao in 2007 merged with a dairy producer Eleva and then created Brasil Foods with Sadia. ${ }^{12}$ This newly created company has acquired the status of the largest Brazilian TNC as well as the largest poultry exporter in the world, which means that Brasil Foods is very powerful because of its enormous scale of chicken business (Bell \& Kindred, 2013).

In 2012, South Africa limited Brazilian chicken imports with anti-dumping duties. Under the pressure of Brasil Foods, Brazilian government lodged a trade dispute against South Africa at the WTO. Brazil argued that South Africa did not consider factors such as the export price and the normal price as charged in the Brazilian market, and failed to specify the information necessary to ensure fair comparison of the prices charged in Brazil and South Africa. In fact, driven by the rise of poultry industry, Brazilian government and its TNCs have allied together to aggressively pursue the expansion of markets globally through the WTO dispute settlement mechanism in the past few years. Such an aggressive and export-oriented industry has transformed the relationship between the government and TNCs. For instance, Brasil Foods has close ties to Lula's cabinet; many officials of Development, Industry and Foreign Trade previously worked for Sadia or Perdigao. The poultry industry therefore is a powerful force in Brazilian politics with considerable influence in shaping trade policy.

Brazil's dispute with South Africa was interesting to some degree because several unclear factors contributed to

12 The merger exhibited the Brazilian government's intention to support its TNCs. 
the abandonment of this dispute proceedings at the WTO (WTO, 2012). According to Hilton Zunckel and Lambert Botha, South Africa and Brazil are close political allies; both are BRICS members (Zunckel \& Botha, 2012). The relationship based on that probably explains a bit why the two developing countries did not really fight a trade war; however, this case highlights that while political alliance do have some influence on international trade dispute, ultimately a country's domestic interests play a more dominant role in deciding trade policy (Milner, 1997). Obviously, South Africa was threatened by a serious loss of local jobs and decided to take the measure of imposing antidumping duties on chicken from Brasil Foods. Similarly, the existence of the BRICS would not deter poultry and other businesses to ask the Brazilian government to ensure their interests in the following years after this chicken war (Hopewell, 2014). Simply put, domestic politics usually dominated by TNCs shape international trade interaction.

\section{Conclusion}

When we see TNCs wielding their economic power over sovereign states (either mother countries or host countries) in some cases, the logical next step for us is to ask under what conditions TNCs have such a powerful influence in the field of international trade. According to the report issued by United Nations Conference on Trade and Development (UNCTAD), rich developed countries, such as the U.S., are home to third quarter of the world's top 100 TNCs (UNCTAD, 2007: 3). Given this fact and the first two case studies within this paper, it is not hard to image that most developed countries like the U.S. have a commitment to promote their domestic industries interests by pushing to open global trade markets. In fact, the market economy and globalization over the past decades have caused an irreversible phenomenon, which empowers TNCs in many developed countries to become colossal economic powers. The result is that those TNCs are wielding their influence at both the domestic and international level and affecting the policies and regulations issued by target or host countries through their mother countries as the agent at the WTO (Milner, 1988; Reinalda, 2001). As Gregory Shaffer suggested, TNCs know how to adapt public-private collaborative strategy (the PP strategy) to enforce WTO law and advance their interests (2003: 144). In more detail, the PP strategy integrates the interests of businesses and home governments' authorities, being an important tool that TNCs wield in protecting their global market shares.

Actually, many trade disputes heard by the WTO were dispute brought by governments at the instigation of TNCs. All three case studies within this paper, from Banana, Photographic Film and Paper, to chicken, are not exceptional. Furthermore, TNCs will not only lobby home governments to bring dispute settlement cases to the WTO, they also play an important and behind-the-scenes role in planning the legal strategy and drafting the submissions (Guzman \& Hall, 2005; Drope \& Hansen, 2004). In the case studies, particularly the U.S. was involved in, the PP strategy centers on informal channels for lobbying and consultation, petitioning for the U.S. government to combat trade barriers and discriminatory policies enacted by foreign governments. We may deduce from the research findings that exporting countries and their TNCs usually corporate with each other to take advantage of trade liberalization by exerting their power over many importing countries, developing countries in particular. Further, for strategies that applied before the focusing events happened, TNCs used to exercise their influence in a pattern of quiet politics. Doing so, the relationship between governments and businesses could be well maintained without public scrutiny. The Chiquita's case has proved this argument and the Kodak and Brasil Foods' cases are same to a certain extent.

Overall, this paper casts a doubt on the viewpoint offered by state-centric realists, revealing the characteristic of "power" that IR scholars should concern more seriously because the distribution of it is highly asymmetrical in the field of international trade and the owner of such power is usually not sovereign states. Therefore, success in the global trade is dependent on TNCs not on sovereign states in the most of time, and many states are losing control of their autonomy and also losing control over the domestic trade affairs. Given this, the first hypothesis (H1) argued by this paper is proven to be true. Further, the case studies demonstrate that developing countries, e.g., South Africa, are hard to impose constrains on TNCs. Given this, a more liberalized global market very likely empowers certain actors, particularly those who come from the North. In this sense, many sovereign states in the South are probably less able to seize upper hand in international trade, whereas TNCs are in a better position to implicitly dictate to their mother countries, and indirectly influence weaker importing countries. Last but not the least, actors on the stage of international trade that have comparative advantage in doing business are the real power-owner; put otherwise, sovereign state very likely becomes an instrument for TNCs. Given this, the importance or superiority of sovereign state isn't necessarily permanent; conversely, some statements argued by state-centric realism have to be revised. 


\section{Acknowledgments}

The author would like to offer the deepest gratitude to Professor John S. Duffield as well as the editor and anonymous reviewers for their very helpful guidance and solid comments.

\section{References}

Baldwin, D. (2013). Power and International Relations. In W. Carlsnaes, T. Risse, \& B. Simmons (Eds.), Handbook of International Relations (2nd ed., pp. 273-296). London: Sage. http://dx.doi.org/10.4135/9781446247587.n11

Barkham, P. (1999). The Banana Wars Explained. The Guardian. Retrieved from http:/www.theguardian.com/world/1999/mar/05/eu.wto3

Barnett, M., \& Duvall, R. (2005). Power in Global Governance. In M. Barnett, \& R. Duvall (Eds.), Power in Global Governance (pp. 1-31). Cambridge: Cambridge University Press.

Baron, D. (1997). Integrated Strategy, Trade Policy, and Global Competition. California Management Review, 39(2), 145-169. http://dx.doi.org/10.2307/41165891

Bell, D., \& Kindred, N. (2013). Brasil Foods. Doc. No.: 9-512-013, April 10th.

Birkland, T. (1998). Focusing Events, Mobilization, and Agenda Setting. Journal of Public Policy, 18(1), 53-74. http://dx.doi.org/10.1017/S0143814X98000038

Cooper, S., Hawkins, D., Jacoby, W., \& Nielson, D. (2008). Yielding Sovereignty to International Institutions: Bringing System Structure Back In. International Studies Review, 10(3), 501-524. http://dx.doi.org/10.1111/j.1468-2486.2008.00802.x

Culpepper, P. (2010). Quiet Politics and Business Power. Cambridge: Cambridge University Press. http://dx.doi.org/10.1017/CBO9780511760716

Cutler, A. C. (2002). Private International Regimes and Interfirm Cooperation. In R. Hall, \& T. Biersteker (Eds.), The Emergence of Private Authority in Global Governance (pp. 23-40). Cambridge: Cambridge University Press. http://dx.doi.org/10.1017/CBO9780511491238.003

Dahan, N., Doh, J., \& Guay, T. (2006). The Role of Multinational Corporations in Transnational Institution Building: A policy Network Perspective. Human Relations, 59(1), 1571-1600. http://dx.doi.org/10.1177/0018726706072854

Dahl, R. (1957). The Concept of Power. Behavioral Science, 2(3), 201-215. http://dx.doi.org/10.1002/bs.3830020303

DPP Questions Treatment of Wei Ying-chun. Taipei Times (Mon, Oct. 13, 2014). Retrieved from http://www.taipeitimes.com/News/front/archives/2014/10/13/2003601937

Drezner, D. (2007). All Politics is Global. New Jersey: Princeton University Press.

Drope, J., \& Hansen, W. L. (2004). Purchasing Protection? The Effect of Political Spending on U.S. Trade Policy. Political Research Quarterly, 57(1), 27-37. http://dx.doi.org/10.1177/106591290405700103

Duffield, J. (2003). The Limits of Rational Design. International Organization, 57(2), 411-430. http://dx.doi.org/10.1017/S002081830357206X

FAO. (2003). The World Banana Economy: 1985-2002. Rome: FAO.

Fell, D. (2012). Government and Politics in Taiwan. New York: Routledge.

Fletcher, M. (1996). Film Fight: Fuji vs. Kodak. Asia Week. Retrieved from https://www.wto.org/english/tratop_e/dispu_e/cases_e/ds44_e.htm

Frankel, J. (2000). Globalization of the Economy. In J. Nye, \& J. Donahue (Eds.), Governance in a Globalizing World (pp. 45-50). Washington, DC: Brookings Institute.

Frieden, J. (2006). Global Capitalism: Its Fall and Rise in the Twentieth Century. NY: W. W. Norton, pp. 25-27.

Grieco, J., \& Ikenberry, G. J. (2002). State Power and World Markets. NY: W.W. Norton.

Guzman, A. T., \& Hall, B. (2005). Power Plays and Capacity Constraints: The Selection of Defendants in WTO Disputes. Journal of Legal Studies, 34(2), 557-598. http://dx.doi.org/10.1086/430767

Harrison, B. (1997). Lean and Mean: The Changing Landscape of Corporate Power in the Age of Flexibility. NY: Basic Books. 
Hertz, N. (2003). The Silent Takeover. NY: Harper Collins.

Hopewell, K. (2014). The Transformation of State-Business Relations in An Emerging Economy. Critical Perspectives on International Business, 10(4), 291-309. http://dx.doi.org/10.1108/cpoib-03-2014-0019

Josling, T. E. (2003). Bananas and the WTO: Testing the New Dispute Settlement Process. In T. E. Josling, \& T. G. Taylor (Eds.), Banana Wars: the Anatomy of a Trade Dispute (pp. 169-194). California: Institute for International Studies Stanford University. http://dx.doi.org/10.1079/9780851996370.0169

Joyce, R. (2013). Competing Sovereignties. NY: Routledge.

Kose, A., \& Ozturk, E. (2014). A World of Change. Finance \& Development, 51(3), 6-11.

Krasner, S. (1982). Structural Causes and Regime Consequences: Regimes as Intervening Variables. International Organization, 36(2), 185-205. http://dx.doi.org/10.1017/S0020818300018920

Levy, D., \& Prakash, A. (2003). Bargains Old and New: Multinational Corporations in Global Governance. Business and Politics, 5(2), 131-150. http://dx.doi.org/10.1080/1369525032000125358

Lida, K. (2006). Legalization and Japan: The Politics of WTO Dispute Settlement. London: Cameron May.

Milner, Helen. (1988). Resisting Protectionism: Global Industries and Politics of International Trade. Princeton: Princeton University Press.

Milner, Helen. (1997). Interests, Institutions, and Information: Domestic Politics and International Relations. Princeton: Princeton University Press.

Montevideo Convention on the Rights and Duties of States.

Naím, M. (2013). The End of Power. NY: Basic Books.

Patterson, D., \& Afilalo, A. (2008). The New Global Trading Order. Cambridge: Cambridge University Press.

Reinalda, Bob. (2001). Non-State Actors in the International System of States, in Bas Arts, Math Noortmann, Bob Reinalds, eds., Non-State Actors in International Relations. Aldershot: Ashgate, 3-17.

Scherer, A. G., Palazzo, G., \& Baumann, D. (2006). Global Rules and Private Actors: Towards a new Role of the Transnational Corporation in Global Governance. Business Ethics Quarterly, 16(4), 505-532. http://dx.doi.org/10.5840/beq200616446

Shaffer, G. (2003). Defending Interests: Public-Private Partnerships in WTO Litigation. Washington: Brookings Institution.

Shah, A. (2010). The Banana Trade War. Global Issue. Retrieved from http://www.globalissues.org/article/63/the-banana-trade-war

Stein, A. (1993). Coordination and Collaboration. In D. Baldwin (Ed.), Neorealism and Neoliberalism: The Contemporary Debate (pp. 29-58). NY: Columbia University Press.

Strange, S. (1991). Big Business and the State. Millennium-Journal of International Studies, 20(2), 245-250. http://dx.doi.org/10.1177/03058298910200021501

Strange, S. (1995). The Defective State. Daedalus, 124(2), 55-74.

Strange, S. (1996). The Retreat of the State: The Diffusion of Power in The World Economy. Cambridge: Cambridge University Press. http://dx.doi.org/10.1017/CBO9780511559143

Tan, Wei-En and Yu-Tai Tsai. (2012). Who Owns the WTO? On the Participation of NGOs and TNCs in the WTO, in Connie Guang-Hwa Yang, ed., $12^{\text {th }}$ International Trade Law Conference Proceedings. Taipei: Center of International Trade Law and Policy, 397-466.

Turner, S. (1997). Theoretical Framework for the Information Age. Southeastern Political Review, 25(2), 303-324. http://dx.doi.org/10.1111/j.1747-1346.1997.tb00841.x

UNCTAD. (1992). World Investment Report 1992: Transnational Corporations as Engines of Growth.

UNCTAD. (2007). The Universe of the Largest Transnational Corporations. NY: United Nations.

Unesi, E. (n.d.). From Dumping to Production Allocation. Retrieved from http://www.diva-portal.org/smash/get/diva2:319/fulltext01

USDA Foreign Agricultural Service, Brazil: Poultry and Products Annual Report (GAIN Rept. No.: BR 0940).

Vernon, R. (1976). Multinational Enterprises in Developing Countries: Issues in Dependency and 
Interdependence. In D. Apter, \& L. Goodman (Eds.), The Multinational Corporation and Social Change (pp. 40-62). NY: Praeger.

Waltz, K. (1979). Theory of International Politics. MA: Addison-Wesley Publishing Co.

Wiley, J. (2008). The Banana: Empires, Trade Wars, and Globalization. Lincoln: University of Nebraska Press.

WTO. (n.d.). South Africa - Anti-Dumping Duties on Frozen Meat of Fowls from Brazil. WT/DS439/1, G/L/990, G/ADP/D92/1 (25 June 2012).

WTO. (n.d.). European Communities-Regime for the Importation, Sale and Distribution of Bananas. Retrieved from https://www.wto.org/english/tratop_e/dispu_e/cases_e/ds27_e.htm

WTO. (n.d.). Japan-Measures Affecting Consumer Photographic Film and Paper. Retrieved from https://www.wto.org/english/tratop_e/dispu_e/cases_e/ds44_e.htm

WTO. (n.d.). The European Union and the WTO. Retrieved from http://www.wto.org/english/thewto_e/countries_e/european_communities_e.htm

Zunckel, H., \& Botha, L. (2012). The BRICS, South Africa and dispute settlement in the WTO. SAFPI Policy Brief, (9).

\section{Copyrights}

Copyright for this article is retained by the author(s), with first publication rights granted to the journal.

This is an open-access article distributed under the terms and conditions of the Creative Commons Attribution license (http://creativecommons.org/licenses/by/3.0/). 